\title{
Association between foot types defined by static and dynamic measures, and the centre of pressure during gait
}

\author{
Su Liao ${ }^{1}$, Hannah L Javis ${ }^{2}$, Anmin Liu², Christopher J Nester ${ }^{*}$, Peter P Bowden², Richard K Jones ${ }^{2}$, Kaiyu Xiong ${ }^{1}$ \\ From 4th Congress of the International Foot and Ankle Biomechanics (i-FAB) Community \\ Busan, Korea. 8-11 April 2014
}

\section{Background}

Foot types (e.g. pronated, supinated foot) are used for clinical reasoning [1] and widely assumed to be related to centre of pressure (COP) patterns [2,3]. Specifically, a pronated foot will demonstrate a medially deviated COP. It follows that COP could be a measure of foot type and inferences about function extrapolated from it. The purpose of this study was to investigate whether COP parameters differ between foot types.

\section{Methods}

Static foot posture, foot kinematics and COP data were collected on 90 healthy subjects during walking (Figure 1). The subjects were classified as pronated, supinated, and neutral groups using three static and four dynamic methods (table 1). COP lateral and medial excursion area, COP lateral medial difference (COP_LMD), and COP index (COP_I) were calculated for different phases of stance [4-6]. Independent $T$ test and correlations were calculated among the different groups.

\section{Results}

Pronated feet (based on FPI) demonstrated more medial excursion of the COP from heel strike to heel off $(\mathrm{p}<0.05)$. Pronated feet classified by NCSP-RCSP demonstrated higher COP_I during HO-TO $(\mathrm{p}<0.05)$.

Supinated feet classified by NCSP-RCSP and RRE had more medial excursion of the COP (COP-ME) during HO-TO $(\mathrm{p}<0.05)$. Feet classified as supinated by TPRE resulted in a greater COP-LMD in a stance $(\mathrm{p}<0.05)$ and their COP_I was statistically significantly higher. Feet classified as supinated by RRE showed higher COP-LMD

\footnotetext{
* Correspondence: c.j.nester@salford.ac.uk

${ }^{2}$ School of Health Sciences, University of Salford, Salford, M6 6PU, UK

Full list of author information is available at the end of the article
}

value during $\mathrm{HO}-\mathrm{TO}(\mathrm{p}<0.05)$. The statistical results showed a weak relationship between COP parameters of different foot types $(r<0.27)$. Dynamic measures of foot type showed a slightly stringer association to COP measures than static measures of foot type.

\section{Conclusion}

Over all, whilst there were some differences between foot types in some COP measures, the meaning of the observed differences does not support the hypothesis that COP parameters are strongly indicative of specific

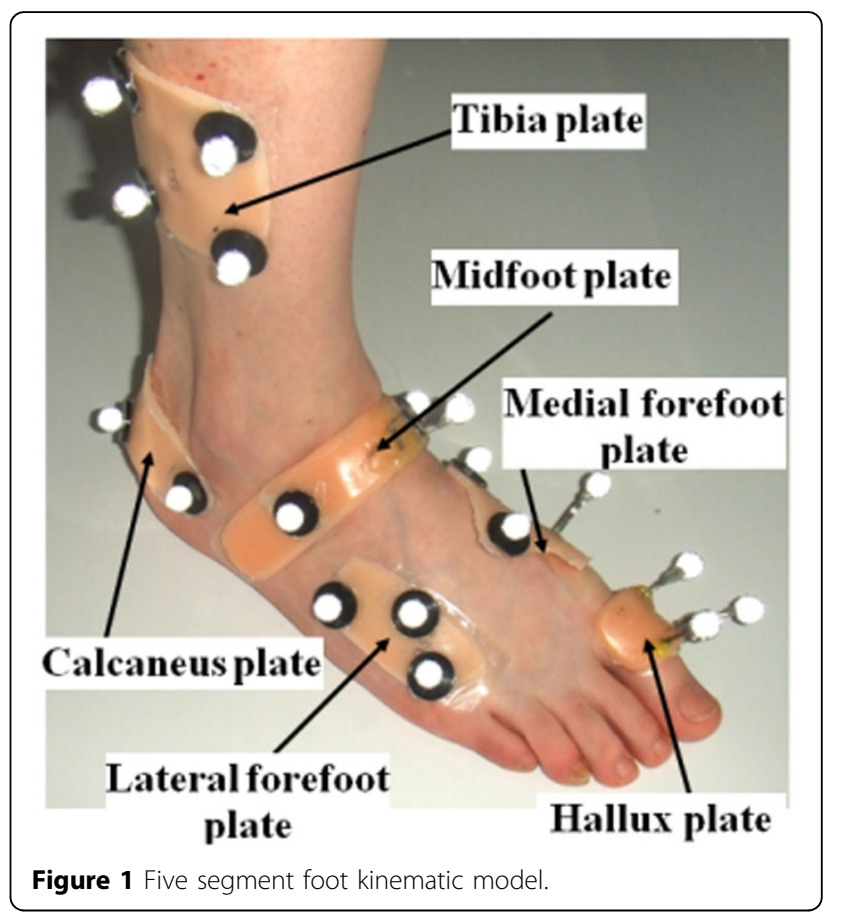


Table 1

\begin{tabular}{lll}
\hline Classification method & Pronators & Supinators \\
\hline Foot Posture Index(FPI) & $\geq 7$ & $\leq-1$ \\
\hline Resting Calcaneal Stance Position (RCSP) & $\leq-2^{\circ}$ & $\geq 3^{\circ}$ \\
\hline Difference between NCSP ${ }^{*}$ and RCSP & $\geq 8^{\circ}$ & $\leq 4^{\circ}$ \\
\hline Peak Rearfoot Eversion(PRE) & $\leq-6.1^{\circ}$ & $\geq-1.1^{\circ}$ \\
\hline Time of Peak Rear foot Eversion (TPRE) & $\geq 38 \%$ & $\leq 26 \%$ \\
\hline Range of Rearfoot Eversion (RRE) & $\geq 16.3^{\circ}$ & $\leq 10.5^{\circ}$ \\
\hline Maximum Mid Foot Dorsiflexion & $\geq 6.4^{\circ}$ & $\leq 1.1^{\circ}$ \\
\hline *NCSP.neutral calcaneal stance position & &
\end{tabular}

foot types. Thus, COP measures should not be used to infer foot kinematic nor foot function.

\section{Authors' details}

'Sport Science College, Beijing Sport University, Beijing, 100084, China.

${ }^{2}$ School of Health Sciences, University of Salford, Salford, M6 6PU, UK.

Published: 8 April 2014

\section{References}

1. Rao Smita, Riskowsk L Jody, Hannan T Marian: Musculoskeletal conditions of the foot and ankle: Assessments and treatment options. Review Article Best Practice \& Research Clinical Rheumatology 2012, 26(3):345-368.

2. Dixon SJ: Application of Centre-of-Pressure Data to Indicate Rear foot Inversion-Eversion in Shod Running. Journal of the American Podiatric Medical Association 2006, 96(4):305-12.

3. Han TR, Paik NJ, Im MS: Quantification of the path of centre of pressure (COP) using an F-scan in-shoe transducer. 1999, 10:248-54.

4. Redmond AC, Crane1 YZ, Menz HB: Normative values for the Foot Posture Index. Journal of Foot and Ankle Research 2008, 1(6).

5. Sobel Ellen, et al: Re-evaluation of the Relaxed Calcaneal Stance PositionReliability and Normal Values in Children and Adults. J Am Podiatric Med. Assoc 1999, 89(5):258-64.

6. Landorf K, Keenan AM, Rushworth RL: Foot Orthosis Prescription Habits of Australian and New Zealand Podiatric Physicians. J Am Podiatric Med. Assoc 2001, 91(4):174-83.

doi:10.1186/1757-1146-7-S1-A55

Cite this article as: Liao et al: Association between foot types defined by static and dynamic measures, and the centre of pressure during gait. Journal of Foot and Ankle Research 2014 7(Suppl 1):A55.

\section{Submit your next manuscript to BioMed Central and take full advantage of:}

- Convenient online submission

- Thorough peer review

- No space constraints or color figure charges

- Immediate publication on acceptance

- Inclusion in PubMed, CAS, Scopus and Google Scholar

- Research which is freely available for redistribution

Submit your manuscript at www.biomedcentral.com/submit
C) Biomed Central 